\title{
COVID-19-krisen: Forløb og bekymringer
}

\author{
Artikel 1 \\ PETER B. ANDERSEN, BRIAN ARLY JACOBSEN, LENE KÜHLE, HENRIK \\ REINTOFT CHRISTENSEN, HEIDI FRØLUND PEDERSEN, HANNE \\ WÜRTZEN, PETER LA COUR \& JESPER F. SØRENSEN
}

ENGLISH ABSTRACT: This article offers an overview over the political steps and containment proceedures during the first months of the COVID-19 pandemic in Denmark 2020

DANSK RESUME: Denne artikel leverer en oversigt over og en gennemgang af de konkrete politiske indgreb, som den danske regering foretog med henblik på at opdxmme smittespredning $i$ de første måneder af COVID-19-pandemien i Danmark 2020.

KEY WORDS: COVID-19; COVID-19 and religion; COVID-19-pandemic line of events in Denmark; COVID-19 and psychological crisis; COVID-19 and wellbeing

Denne artikel har først og fremmest til formål at fungere som opridsning af konkrete hændelsesforløb, som på affattelses- og udgivelsestidspunktet kan forekomme overflødige, fordi de stadig står frisk i erindring. Men i ønsket om at øge muligheden for, at dette temanummer af Religionsvidenskabeligt Tidsskrift også vil kunne være tilgængeligt for fremtidige læsere, indføjer vi her som indledningsartikel en skitse til overblik over hændelsesforløb og konkrete politiske tiltag under COVID-19-epidemiens første måneder i Danmark.

COVID-19 udbruddet begyndte i den kinesiske storby Wuhan, hvor det formodentlig daterer sig tilbage til den første uge af december 2019, og hvor der midt i måneden blev indlagt patienter med en lungebetændelse med 'atypiske symptomer' . Den 30. december informerede byens sundhedsmyndigheder offentligheden og dagen efter, den 31. december, underrettede de kinesiske myndigheder World Health Organization (WHO) (Thøgersen 30. juni 2020). Den 'atypiske lungebetændelse' blev i slutningen af december 2020 identificeret som en 'ikke tidligere set coronavirus', og i løbet af januar 2020 kunne man i de danske medier følge, hvordan de kinesiske myndigheders arbejde for at inddæmme epidemien lagde gaderne i Wuhan øde. Mange almindelige borgere i Europa må have tænkt tilbage på SARS (Severe Acute Respiratory Syndrome) epidemien, der efter dens opdukken i 2002 svækkedes i en sådan 
grad, at den forsvandt fra den offentlige bevidsthed i 2004. I modsætning hertil spredte COVID-19 sig med drastiske følger over store dele af verden. 20. januar 2020 identificerede man de første patienter med COVID-19 i USA, 31. januar i Norditalien, Spanien og England, den 25. februar i Østrig og den 27. februar i Danmark.1 Endelig, 30. januar 2020 erklærede World Health Organisation (WHO) COVID-19-udbruddet for en international sundhedskrise og den 11. marts 2020 opgraderede WHO niveauet til en pandemi. Historien om pandemien kan fortælles fra mange perspektiver. I denne rapport vil vi fokusere på de eksistentielle, religiøse og trivselsmæssige konsekvenser for den danske befolkning. For at kunne se dem i kontekst er der nyttigt at følge pandemiens udvikling og hvordan truslen fra pandemien blev formuleret og ageret på af danske myndigheder og medier.

Efter at have fokuseret på situationen i Wuhan ændrede mediernes dækning sig gradvist efterhånden som de europæiske lande blev ramt. Danske tv-kanaler og aviser dokumenterede således tidligt, hvordan sundhedssystemet i en lang række lande kom under et ekstremt pres. I den indledende fase af epidemien i Europa og USA, regnede man med, at især ældre var udsatte, mens yngre mennesker og børn nok kunne blive smittede, men at det hos disse ville udtrykke sig asymptomatisk. I denne fase vidste man ikke med sikkerhed, hvordan smitten spredte sig, og myndighedernes råd var derfor generelt at holde afstand til andre mennesker og i øvrigt undgå unødig social kontakt. Det førte til, at lande som Danmark indførte en strategisk 'nedlukning', mens andre lande gik videre og indførte egentlige regionale eller nationale udgangsforbud. Disse tiltag havde alle steder både direkte og indirekte meget drastiske følger for økonomien, med en nærmest paralyse af turist-, hotel- og restaurationsbranchen og mange steder med en midlertidig indstilling af industriel produktion.

Alt dette udgjorde en række helbredsmæssige og økonomiske risici, som potentielt havde drastiske følger for de enkelte borgere: Bliver jeg syg? Hvad er min chance for at klare mig igennem, hvis jeg blive syg? Er jeg nødt til at erklære den virksomhed, jeg har bygget op med mit hjerteblod konkurs? Bliver jeg arbejdsløs? Sådanne spørgsmål var så småt blevet aktuelle, da statsminister Mette Frederiksen onsdag 11. marts 2020 tonede frem på en ekstraordinær pressekonference sendt samtidig på flere nationale TV-kanaler. COVID-19 var da blevet erklæret en pandemi, og regeringen meddelte nu, at den havde valgt at "lukke Danmark ned". Statsministeren understregede, at det i situationen ville være umuligt at undgå fejl, også for hende, men udstrålede på pressekonferencen en beslutsom ro, og kunne, når der blev stillet spørgsmål, der

\footnotetext{
${ }^{1}$ Sundhedssystemet har haft fokus på den første identificerede patient, patient 0 ud fra en interesse om at bryde smittekæderne. Patient 0 viser sig undertiden senere ikke at være den første med en given smitsom sygdom. Her tjener oplysningerne om patient 0 til at oplyse læseren om tidspunkter hvornår sygdommens tilstedeværelse først blev konstateret forskellige steder i verden. Ud over trykte referencer skal her henvises til, at Wickipaedia i en række engelsk og dansksprogede artikler med fokus på 'aktuelle begivenheder' under stadig opdatering følger Covid-19's udvikling, bl.a. “Coronaviruspandemien i 2019-2020”, https://da.wikipedia.org/wiki/Coronaviruspandemien_i_2019-2020. I Danmark opdaterer Videnskab.dk løbende hjemmesiden https://videnskab.dk/topic/covid-19.
} 
berørte tekniske emner, henvise til direktøren i Sundhedsstyrelsen, sundheds- og ældreministeren, rigspolitichefen og direktøren for Borgerservice i Udenrigsministeriet, som alle var til stede på mødet.

Begrebet 'nedlukning,' som godt nok fandtes på dansk tidligere, fik med statsministerens meddelelse en helt ny betydning. $\mathrm{Nu}$ var det ikke længere blot maskiner, rør, lokalradioer eller atomkraftværker, men hele landet som blev lukket ned2, helt lig det engelske lockdown som ofte forekommer som synonym på dansk. Indendørsarrangementer for mere end 100 personer blev forbudt. Skoleelever og studerende på alle uddannelsesinstitutioner blev sendt hjem, hvor de så vidt muligt modtog undervisning over internettet. Dagtilbud til børn blev lukkede. I håndteringen af den Spanske syge i 1918 tøvede myndighederne med at lukke kirker etc., med henvisning til at folk havde behov for et sted at søge trøst (artikel 3, "Undersøgelsens historiske og teoretiske baggrund"). Men på lige fod med andre offentlige og civilsamfundsorganisationer blev religiøse institutioner også lukket ned for at undgå spredning af COVID-19. Offentlige kirkelige forsamlinger, gudstjenester såvel som sociale arrangementer, blev således indstillet. Kirkeministeriet understregede at "Kirkelige handlinger som dåb, bryllup og begravelse/bisættelse er ikke offentlige men er omfattet af forbud mod forsamling af flere end 100 mennesker" (Kirkeministeriet 12. marts 2020, se også Bekendgørelse nr. 224 af 17. marts 2020). Så mange deltagere er sjældne ved disse ritualer, ikke desto mindre var erfaringen, at de også blev aflyst grundet nedlukningen. Ja, selv jordfæstelse af kister i fri luft blev belagt med restriktioner om hvem, der kunne deltage. Kort tid efter fulgte regulering der udstrakte nedlukningen af Folkekirken til andre trossamfund (Sundheds- og Ældreministeriet, Bekendgørelse nr. 370 af 4. april 2020) med virkning fra 5. april. Nedlukningen af religiøse institutioner omfattede således påske (5. - 13. april), pesach (8. - 16. april), vaisakhi, sikhismens fejring af Khalsabroderskabets indstiftelse af Guru Gobind Singh (19. april), ramadan (23. april - 23. maj 2020), og Buddhas fødselsdag, vesak (7. maj).

Alle offentligt ansatte, der varetog ikke-kritiske funktioner blev sendt hjem, og i den udstrækning, det var muligt, skulle selv kritiske funktioner varetages hjemmefra. Private arbejdsgivere blev opfordrede til at lade så mange ansatte som muligt arbejde hjemmefra. Indendørs kulturinstitutioner, som museer og biblioteker, skulle lukke. Borgerne blev anmodet om at begrænse deres brug af offentlig transport. I forlængelse af mediernes dækning af kapacitetsproblemer på særligt de norditalienske sygehuse, gennemgik den danske sundhedssektor en omfattende omstrukturering. For at håndtere de forventede store behov for både almen- og intensivbehandling af COVID-19 patienter, blev ikke-akutte operationer udskudt, ligesom garantier for sundhedsfaglig udredning og behandling af sygdomme inden for bestemte maximale tidsperioder blev midlertidigt ophævet. Sygehuse og plejehjem blev også opfordret til at skærpe restriktioner i forbindelse med besøg.

2 Denne sætning sammenfatter leksikonfund på 'nedlukning' og at 'nedlukke' i Den danske Ordbog og KorpusDK på ordnet.dk (tilgået 1 . september 2020). Wikipedia gennemgår udviklingen engelske begreb 'lockdown' under Covid-19 udbruddet (https://en.wikipedia.org/wiki/Lockdown tilgået 23. september 2020). Lockdown kan på dansk bruges specifikt om hjemsendelse af de offentlige ansatte hvor de skal arbejde hjemmefra. 
Når vi ser på Danmarks forhold til udlandet, så fandt der også en række drastiske ændringer sted. Danskere i udlandet blev rådet til at vende hjem hurtigst muligt (dvs. alle der ikke havde opgaver i udlandet), og grænserne til Danmark lukkede for almindelig turisme. Kun udlændinge med et 'anerkendelsesværdigt formål', her hovedsageligt forstået som arbejdsopgaver, måtte krydse grænserne til Danmark. Udenrigsministeriet frarådede også alle ikke-nødvendige rejser til alle lande i verden. Et råd der kan forstås ud fra pandemi-begrebet: COVID-19 blev set som tilstedeværende overalt i udlandet, og borgere bosiddende i Danmark skulle helst ikke komme i forbindelse med smittekilder, og dermed risikere at bringe smitten med tilbage til Danmark. Man søgte dog samtidig at opretholde den internationale transport til og fra danske produktionsvirksomheder samt, helt centralt, til fødevaresektoren ved at tillade gods at krydse grænserne til og fra Danmark - også når transporterne på lastbil krævede at chauffører krydsede grænsen til Danmark.

Kigger vi herefter på de mere intime sociale relationer, så vi også en hidtil uset statslig indblanding i forholdet mellem borgerne. Vi har allerede omtalt forsamlingsforbuddet, der også gjaldt private sammenkomster og fester. Ud over den allestedsnærværende opfordring til at holde afstand, først 2 siden 1 meter, samt den konstante indprentning af vigtigheden af at hoste og nyse i ærmet samt god håndhygiejne gennem håndvask og afspritning, opfordrede myndighederne også til, at man på ubestemt tid afholdt sig fra gængse hilse- og omgangsformer, som for eksempel kindkys, kram og håndtryk. Vi så altså ikke kun den voldsomste indgriben i den økonomiske sfære siden 2. verdenskrig, men også en hidtil uset statslig regulering af interaktion borgerne i mellem. Der var ikke tale om et udgangsforbud, som man havde indført nogle steder i udlandet. Borgerne kunne netop frit færdes i hele landet, også med de kollektive transportmidler. De blev godt nok frarådet at rejse udenlands, men dog ikke forbudt at rejse.3

Ser vi på lovgrundlaget, kan vi bemærke, at nedlukningen først trådte i kraft lørdag 14. marts 2020, på trods af, at statsministeren allerede annoncerede den om onsdagen. Det var dog ikke muligt så hurtigt at gennemføre alle dens detaljer i henhold til dansk lov så hurtigt, hvorfor ikrafttrædelsen måtte afvente Folketingets vedtagelse. Denne kom imidlertid på plads med opbakning fra alle de øvrige partier i Folketinget, som må have været inddraget i forhåndsdrøftelser. For torsdag 12. marts 2020 kunne folketinget gennemføre tre behandlinger af en særlov Lov om ændring af lov om foranstaltninger mod smitsomme og andre overførbare sygdomme (L133), som blev enstemmig vedtaget. Den korte lovtekst, som foreløbigt gælder indtil 1. marts 2021, tillader sundheds- og ældreministeren i samarbejde med justitsministeren at gennemføre den nedlukning, som statsministeren dagen inden havde bekendtgjort, ligesom ministrene får mulighed for at indføre yderligere tiltag (Fig 1.1 og 1.2).

\footnotetext{
${ }^{3}$ Der findes mange sammenfatninger og flere områder end de nævnte var også berørte af nedlukningen. Dette afsnit er skrevet med udgangspunkt i den tidlige summering, som findes i Mester Tidende 13. marts 2020, der har fungeret som emneliste. Udenrigsministeriets opfordring på pressemødet onsdag 11. marts 2020 om, at danskere i udlandet skulle vende hjem var formuleret i absolutte vendinger. Det var dog ikke hensigten eftersom folk, der havde længere ophold ikke nødvendigvis var omfattede af opfordringen.
} 
Et yderligere tiltag kom kort efter. Onsdag 18. marts 2020 blev nedlukningen udvidet til at omfatte kollektive sportsaktiviteter, cafeer, værtshuse, restauranter, frisører og storcentre, på nær fødevarebutikker og apoteker i storcentrene. Idrætscentre blev nedlukkede og turneringer blev aflyst eller udskudt.

Fig. 1.1. COVID-19 indlæggelser og dødsfald fra 1. marts til 30. september 2020

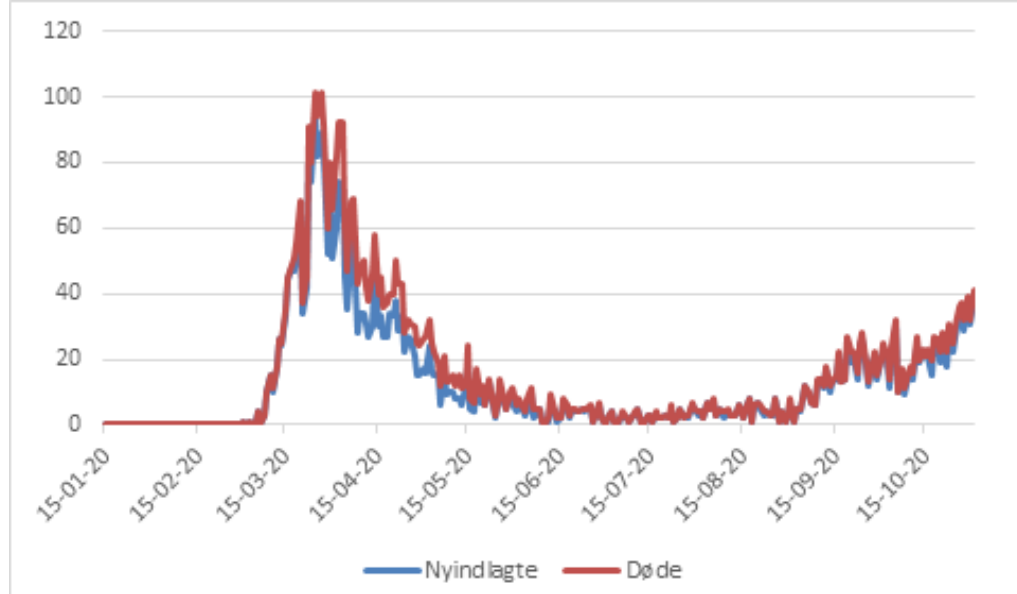

Statens Seruminstituts (SSI) overvågningsdata registrerer den første indlæggelse 1. marts 2020 og det første dødsfald 11. marts 2020. Data fra Statens Seruminstituts overvågningsdata (https://COVID19.ssi.dk/overvagningsdataldownload-fil-med-overvaagningdata, tilgået 30. november 2020)

Fig. 1.2. Nye tilfælde af COVID-19 fra 1. februar til 30. september 2020

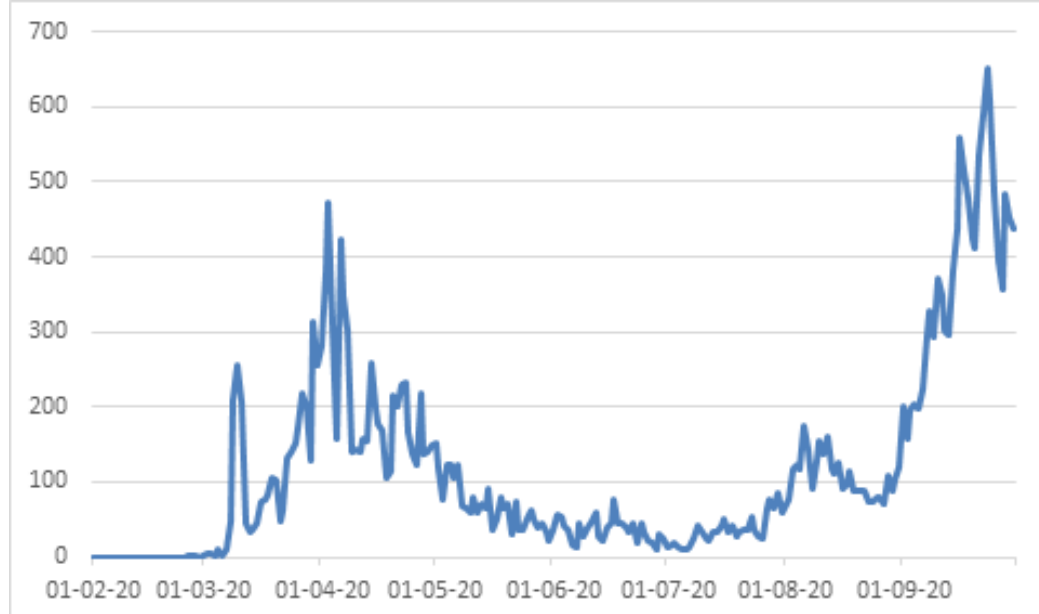

Statens Seruminstituts (SSI) overvågningsdata registrerer det første COVID-19 - tilfxlde 26. februar 2020. Grafen dækker perioden fra 1. februar 2020 til 30. september 2020. Testkapaciteten blev løbende øget fra den første enkelte (negative) test af en person 27. januar 2020 til, at der 29. september 2020 blev testet 50.700 for efter denne figur, ved at have nået omkring 80.000 personer om dagen udgangen af november 2020. Relationen mellem gennemførte test og positive test lå igennem hele denne periode på omkring mellem 1 og 2 procent positive test. Data fra Statens Seruminstituts overvågningsdata (https://COVID19.ssi.dk/overvagningsdata/download-fil-med-overvaagningdata, tilgået 30 . november 2020). 


\section{De to kurver}

Det var hele vejen igennem krisen regeringens eksplicitte mål at undgå en overbelastning af sundhedsvæsnet, hvilket ville forhindre det $\mathrm{i}$ at behandle alle patienter med COVID-19 ud fra det basale princip, at der er "let og lige adgang til sundhedsvæsenet" for alle (som det udtrykkes i Sundhedsloven $§ 2$, af 1. januar 2007) samt forhindre behandlingen af andre akutte og livstruende sygdomme. Sundhedsmyndighederne illustrerede overvejelserne ud fra den grafiske fremstilling af 'de to kurver', som bl.a. sundheds- og ældreministeren viste frem på et pressemøde i Statsministeriet (onsdag 11. marts 2020). Illustrationen viser to hypotetiske fremskrivninger af antallet af smittede, hvor smitten i begge tilfælde antages at have en jævn udvikling og have lige store muligheder for at nå nye raske individer. Den første af kurverne viser en hurtig vækst og et hurtigt fald i antallet af smittede, hvilket er den forventede udvikling, såfremt man ikke søger at begrænse smitten. I dette scenarie forventes antallet af syge langt at overstige sundhedsvæsnets kapacitet og vil således føre til, at man må forvente et stort antal dødsfald, både af COVID-19 patienter, der kræver intensiv behandling, og af andre akut opståede sygdomme, der ikke behandles pga. kapacitetsmangel. Den anden kurve illustrerer en situation, som også er markeret på billedet. Her har myndighederne sat ind med forskellige initiativer, der begrænser smittens udbredelse. Forventningen til dette scenarie er, at spredningen vil gå langsommere med det resultat, at det vil være muligt at holde antallet af syge nede, så sundhedsvæsnets kapacitet ikke overskrides. Her kan man så forvente et langt lavere antal af dødsfald.

Figuren (1.3) med 'de to kurver' går tilbage til 2007 og blev videre udviklet af de amerikanske myndigheder efter N1H1 influenzaen i 2009. Et af mange punkter myndighederne overvejede, var forholdet mellem foranstaltninger, som de enkelte individer tog frivilligt og på egen hånd, over for foranstaltninger indført af myndighederne. Analysen kom ud med en klar anbefaling af, at det til at bekæmpe og inddæmme en pandemi var nødvendigt, at myndighederne ikke overlod initiativet til de enkelte individer, men også indførte tvungne foranstaltninger (Community Mitigation Guidelines 2017). Råd som de danske myndigheder og regeringens tiltag var på linje med.

Figur 1.3. De to kurver

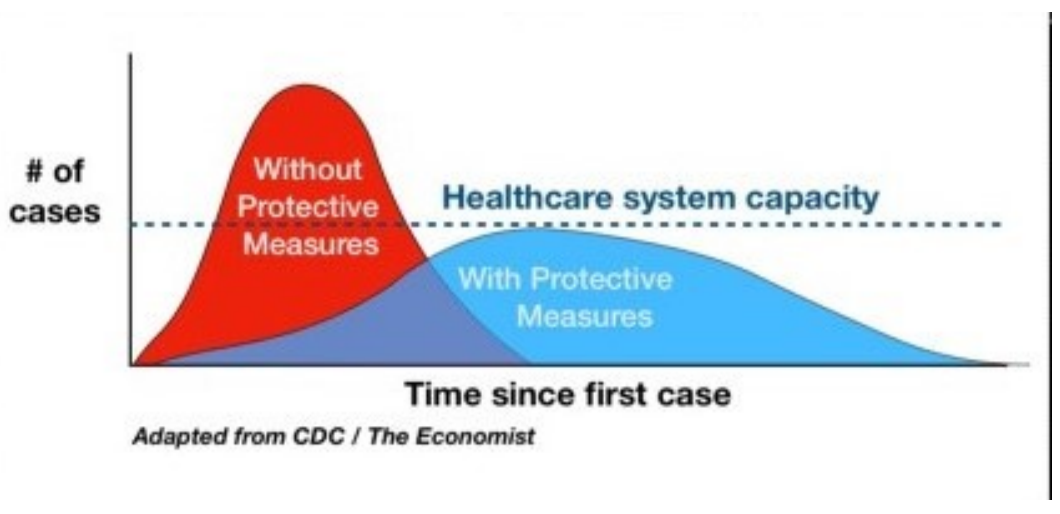


Figur Drew Harris, fra Marc Wilson i The story behind 'flatten the curve,' the defining chart of the coronavirus, Fastcompany. Her gengivet fra Videnskab.dk.

Efterhånden som smittetallene faldt (Figur 1.1 og 1.2), blev det klart, at man igen gradvis kunne åbne for visse aktiviteter. Den 30. marts 2020 meddelte statsministeren, at en række virksomheder, der havde været underlagt total nedlukning nu kunne genåbne, hvis de overholdt bestemte retningslinjer. Det gjaldt liberale erhverv, hvor det er umuligt at undgå tæt fysisk kontakt med kunderne, herunder frisører, massagekliniker, tandlægeklinikker, og køreskoler, som fik lov at åbne igen den 20. april 2020. Dagtilbud og grundskolen fra 1. til 5. klasse blev åbnet 15. april 2020, og man tog fat på at organisere, hvordan afgangsklasserne i gymnasieskolen og HF kunne modtage undervisning, inden de skulle til eksamen.

Detailhandlen, inklusive storcentrene kunne fra 11. maj 2020 åbne igen, restauranter, værtshuse og cafeer 18. maj 2020, ligesom 6. til 10. klasserne fik lov at vende tilbage til skolerne samme dag. Selvom kravene angående antal personer pr. m2 gav detailhandelen visse problemer, kunne butikkerne jævnt hen håndtere det. Anderledes var det med skoler, restauranter, værtshuse og cafeer, der var indrettede til, at flere mennesker samtidigt var samlede i rum af begrænset størrelse. Igen kan det ses, at religiøse institutioner betragtes som en del af henholdsvis den offentlige og frivillige sektor. Folkekirken og andre trossamfund kunne ligeledes genåbne for religiøse forsamlinger fra 18. maj 2020, med restriktioner på hvor mange man måtte være i rummet, og hvordan man måtte interagere. Fra den 27. maj 2020 fik museer, zoologiske haver, forlystelsesparker og lignende lov at genåbne. De videregående uddannelser fik ligeledes tilladelse til at afholde tilstedeværelseseksaminer fra denne dag, hvilket mange benyttede sig af. Stadig flere aktiviteter blev åbnet, restauranter, værtshuse og cafeer med restriktioner for lukketider, egentlige natklubber forblev dog lukkede; hvis de da ikke kunne ændres til at fungere som noget andet, for eksempel cafe eller restaurant. Undervejs er forsamlingsforbud blevet skærpede fra maksimum 100 personer til 50 og endda helt ned til 10 personer, som så blev defineret i forhold til nærmere bestemte arealer, hvor borgernære myndigheder var ude med penslen og male kvadrater på græs og fliser. Politiet måtte flere gange markere særligt overendte steder som corona-hot spots, der kunne blive lukket ned med kort varsel. Idrætten blev først trinvist genåbne, siden blev der atter trin for trin indført en række restriktioner (bl.a. Hestbech 18. september 2020). Genåbningstrinnene blev ledsaget af formanende formuleringer i de officielle skrivelser og en opgradering af den individuelle beskyttelse imod smitte. For eksempel blev der indført krav om at alle medarbejdere og passagerer skulle bære mundbind i offentlige trafik og taxaer fra lørdag 22. august 2020. Hertil kommer, at mundbind blev et generelt krav i butikker, kulturinstitutioner og uddannelsesinstitutioner i slutningen af oktober. Ikke desto mindre blev genåbningen fulgt af lokale stigninger i smittetallene, og nogle steder lukkede private virksomheder ned for en periode (for eksempel Danish Crowns slagteri i Ringsted); og da der var vækst i smittetallene i Aarhus kommune i august 2020 opfordrede Aarhus Universitet sine ansatte til at arbejde hjemme og at både studerende og ansatte skulle afvente nærmere i forhold til om det ville blive muligt at gennemføre studiestart. Det viste sig muligt at bringe smittetallene under kontrol, sådan at universitetet kunne 
byde de studerende velkommen - dog ikke helt som normalt. Fredag 4. september 2020 var smittetallene i Københavnsområdet oppe på så højt et niveau, at regeringen advarede om, at det kunne blive nødvendigt at genindføre nedlukningen, helt eller delvis, hvis det ikke lykkedes at få antallet af smittede til at falde igen. Politiet meddelte i den forbindelse at de ville være meget og synligt, dvs. uniformeret, til stede i nattelivet, for at især de unge skulle undgå at etablere nye smittekæder gennem for tæt kontakt. Da der sker nye udviklinger i pandemien hele tiden har vi måttet lægge et snit et eller andet sted. Vi har valgt at afslutte denne gennemgang med udgangen af september og vil derfor ikke komme ind på den store internationale stigning i smitte i løbet af det sene efterår og heller ikke sagen om de smittede mink, cluster-5 og nedlukningen af syv kommuner i Nordjylland. Medierne har skrevet meget om de eksistentielle kriser mange familier - især minkavlere - har oplevet og det kunne være relevant at have med, men er ikke indfanget af vores undersøgelse der er et øjebliksbillede af situationen i maj.

\section{Politisk analyse af COVID-19-politikken i Danmark}

“Danmark står sammen - ved at holde afstand," udtalte Mette Frederiksen på det velbesøgte pressemøde 11 . marts 2020 og indrammede dermed regeringens og sidenhen befolkningens tilgang til pandemien. Hun fortsatte med at argumentere for, at "Kun på den måde kan vi bryde smittekæden. Det er den danske strategi. Alle Folketingets partier står bag. Vi udfører den i fællesskab." (Mette Frederiksens indledning på pressemøde i Statsministeriet om corona-virus mandag den 11. marts 2020).

Målsætningen var, at smitteraten ikke måtte stige for hurtigt, og at sygdommen skulle kunne håndteres med de nuværende ressourcer på sygehusene. Ligeledes fik regeringen gennem Epidemiloven (L133) mulighed for at lukke ned for alle slags erhverv, der foregår i lokaler som kunderne og offentligheden har adgang til. Regeringen har med et enigt Folketing fra starten understøttet dette lovgivningsmæssigt med en hjemmel til, at sundhedsvæsenet i højere grad kunne prioritere ved at suspendere behandlingsgarantien i en periode. Regeringen appellerede herudover til befolkningen om at holde afstand til hinanden, og opfordrede arbejdsgivere til at bistå med at indrette arbejdspladserne, således at smittekæder ikke opstår. Lovgivningsmæssigt blev muligheden for kontrol og frihedsberøvelse øget, ved at udvide hjemlen hertil i Epidemiloven.

Kommunerne blev desuden pålagt de samme beføjelser og pligter i forbindelse med håndteringen af COVID-19 som statsinstitutioner og andre offentlige institutioner. Det betød, at kommuner kunne forudbetale, give kredit, samt suspendere eller undlade at gøre misligholdelses-beføjelser gældende foreløbigt over for private virksomheder, som kommunen handlede med.

Det er næppe overraskende for de fleste danskere, at statsministeren ikke gav hverken Folkekirken eller religion særlig opmærksomhed, men det er alligevel værd at notere sig. Som vi diskuterer senere kan man argumentere for at krisen produce- 
rede sin egen særlige logik, som kunne siges at minde om religion: Fremstod de jævnlige pressemøder på sin egen vis som ritualer, der samlede befolkningen foran skærmen?

\section{Hjælpepakker}

Regeringen afsatte med Folketinget et større milliardbeløb til forskellige hjælpepakker til erhvervslivet som blandt andet indeholdt hjemsendelsesordning for lønmodtagere og forskellige former for erhvervsstøtte. Initiativet om hjemsendelse blev formuleret for at beskytte lønmodtagere fra at blive afskediget, og blev til som led i en trepartsaftale. De tre parter bestod af regeringen (Socialdemokratiet) og arbejdsmarkedets parter (FH og DA), som 14. marts indgik en "Trepartsaftale om midlertidig lønkompensation for lønmodtagere på det private arbejdsmarked". Som opfølgning på denne aftale tilsluttede Folketingets finansudvalg sig 17. marts 2020 Erhvervsministeriets Aktstykke nr. 108. Det handler om tilslutning til etablering af en midlertidig lønkompensations-ordning, hvorefter virksomheder kan få delvis kompensation for lønudgifter til fyringstruede medarbejdere som følge af COVID-19. Hjælpepakker til Folkekirken? Mange trossamfund, som blandt andet er afhængig af indsamlingerne til gudstjenester og fredagsbøn blev også ramt økonomisk. Det blev ikke diskuteret hvorvidt også trossamfund generelt skulle have en hjælpepakke.

\section{Social- og dagpengehjælp}

Herudover vedtog regeringen at understøtte og forlænge muligheden for sygedagpenge, suspension af dagpengeperioden, den såkaldte 225 timers-regel suspenderedes for en periode samt en række andre initiativer rettet mod det arbejdsmarkeds- og socialpolitiske område. Endelig blev der indgået en midlertidig trepartsaftale om arbejdsfordeling, som muliggjorde, at virksomheder fra den 14. september 2020 kunne indgå lokalaftaler så medarbejdere i en periode kunne hæve arbejdsløshedsdagpenge selvom de ikke blev afskedigede fra virksomheden. Denne ordning gjaldt også ikke arbejdsforsikrede personer (Beskæftigelsesministeriet, Trepartsaftale, August 2020). Hvad angår udlændingeområdet var der ikke enighed i Folketinget, men dog et flertal for regeringens kombination af en udsættelse af tildeling af statsborgerskab uden dog at suspendere kravet om selvforsørgelse. I en tid, hvor arbejdsløsheden stiger markant, stiller regeringen derfor nogle af de mennesker, der bliver arbejdsløse, over for valget mellem ikke at kunne betale deres regninger, eller at frasige sig muligheden for statsborgerskab i 2 år fra det tidspunkt, hvor man igen er selvforsøgende. Ved samme lovbehandling blev en lov vedtaget om strafforhøjelse med faktor 2 ved COVID-19-relateret kriminalitet, og faktor 4 hvis kriminaliteten indebærer økonomisk berigelse. 


\section{Hjemmel til tvang}

Ved loven af 17. marts blev magten for epidemiindsatsen midlertidigt centraliseret hos regeringen, konkret ved sundheds- og ældreminister, Magnus Heunicke (S). Det betød, at der midlertidigt blev indført en hjemmel til privatisering af myndighedsindsatsen, hvis det blev skønnet relevant. Endvidere mulighed for at tvangsbehandle mennesker, og beføjelser til at tvangsisolere smittede. Der blev også indført hjemmel til at bryde ind i folks hjem ved mistanke om smitte - dog ikke uden kendelse, som regeringen ellers indledningsvist havde foreslået. Muligheden for at foretage tvangsvaccination over for smittede blev desuden udvidet til at omfatte al tvangsbehandling af smittede, uanset om der er tale om vaccination eller andre tiltag. Loven bestemmer også, at myndighederne kan foretage tvangsvaccination af udvalgte risikogrupper i befolkningen for andre sygdomme end dén, der bringer epidemiloven i anvendelse, med henblik på at minimere udbredelsen af øvrige sygdomme i befolkningen. Loven bemyndigede herudover ministeren til, at regeringen kan forhindre eller opbryde større forsamlinger eller arrangementer - dog ikke for eksempel politiske forsamlinger.

\section{Modsætningen mellem privat- og erhvervsliv}

Den politiske præmis for regeringens og folketingets arbejde blev tydelig i modsætningen mellem privat- og erhvervsliv. De midlertidige love kontrollerer det private og sociale liv hårdt, mens erhvervslivet undtages for lignende krav, selvom der er sundhedsmæssigt belæg for det (for eksempel hvis man sidder tæt i storrumskontor). Argumentet er åbenbart. Arbejde og erhvervsliv er nødvendigt i den kritiske situation i samfundet - det øvrige liv, for eksempel det religiøse, kulturelle eller sportslige liv, forstås som unødigt. Rationalet synes at være, at samfundet er langt mere sårbart, når økonomien stagnerer, end hvis for eksempel den mentale sundhed lider overlast i en situation med delvis social isolation.

Hastelovene, der særligt gav sundhedsministeren vidtgående beføjelser, og reelt gjorde ham til en af de mest magtfulde ministre i danmarkshistorien, blev af statsretseksperter opfattet som et parlamentarisk problem, hvor Folketinget i praksis blev tilsidesat. Jørgen Grønnegård Christensen, professor emeritus i offentlig forvaltning ved Aarhus Universitet, udtalte bl.a. at "Folketinget er på lange stræk sat fra bestilling. Magten siver fra de folkevalgte, og det er et alvorligt demokratisk problem, må vi som udgangspunkt sige." (Domino, 2. april 2020).

\section{Genåbningsaftalen}

Den 8. maj blev alle Folketingets partier enige om et kompromis for de efterfølgende faser i genåbningen af Danmark. Med en bred aftale om genåbningens efterfølgende faser imødekom statsministeren kravet fra dansk erhvervsliv om en hurtigere genåb- 
ning af økonomien og fordelte samtidig ansvaret for eventuelle negative konsekvenser af genåbningen ud over alle Folketingets partier. Det skete på baggrund af en begyndende kritik og uenighed om genåbningen af Danmark i Folketinget, som dog endte $i$ et kompromis hele Folketinget stod bag. Ikke desto mindre kan man se det som et brud med de primært sundhedsfaglige skøn, som hidtil havde været ledende, i og med at partierne hver især fik lov til at prioritere mærkesager, eksempelvis insisterede Dansk Folkeparti på, at kirkerne skulle genåbnes, selv om landets museer skulle forblive lukkede.

\section{LITTERATUR}

Beskæftigelsesministeriet

2020 "Trepartsaftale om en ny midlertidig arbejdsfordelingsordning på det private arbejdsmarked", https://bm.dk/media/14729/trepartsaftale-arbejdsfordeling.pdf. (Set februar 2021).

Community mitigation guidelines to prevent pandemic influenza - United States

2017 "MMWR. Recommendations and reports : Morbidity and mortality weekly report", Recommendations and reports; 66, no. RR-1, https://stacks.cdc.gov/view/cdc/45220. (Set februar 2021).

Domino, Søren

2020 "Hastelove er kun en ekstrem udgave af den nye normal i dansk politik", Berlingske d. 2. april 2020. (Set februar 2021).

Erhvervsministeriet

2021 "Aktstykke 108. Aktstykke om tilslutning til etablering af en midlertidig lønkompensationsordning, hvorefter virksomheder kan få delvis kompensation for lønudgifter til fyringstruede medarbejdere som følge af COVID-19", https://www.ft.dk/samling/20191/aktstykke/aktstk.108/index.htm . (Set februar 2021).

Hestbech, Lars

2020 "Nye restriktioner rammer idrætten", DIF, https://www.dif.dk/da/forening/nyheder/nyheder/2020/9/18082020 nye-s-restriktioner. (Set februar 2021).

Kirkeministeriet

2020 "Kirker er omfattet af corona-lukning", https://www.km.dk/aktuelt/singlevisning/kirker-eromfattet-af-corona-lukning. (Set februar 2021).

Sundheds- og Ældreministeriet

2020 "Bekendtgørelse om forbud mod større forsamlinger og forbud mod adgang til og restriktioner for visse lokaler i forbindelse med håndtering af Coronavirussygdom 2019 (COVID-19)", Bekendgørelse nr. 224 af 17. marts 2020. (Set februar 2021).

2020 "Lov om ændring af lov om foranstaltninger mod smitsomme og andre overførbare sygdomme (Udvidelse af foranstaltninger til at forebygge og inddæmme smitte samt sikring af kapacitetsmæssige ressourcer m.v.) (L133)". (Set februar 2021).

2020 "Bekendtgørelse om forbud mod større forsamlinger og mod adgang til og restriktioner for lokaler i forbindelse med håndtering af COVID-19", Bekendtgørelse nr. 370 af 4. april 2020. (Set februar 2021).

2007 "Sundhedsloven, ikrafttrådt 1. januar 2007", https://danskelove.dk/sundhedsloven. (Set februar 2021).

Thøgersen, Casper Boyer

2020 “COVID-19-udbruddet i Wuhan: Hvad skete der?", Politiken,30. juni 2020. 
Wilson, Marc

2020 "The story behind 'flatten the curve,' the defining chart of the coronavirus", Fastcompany, https://www.fastcompany.com/90476143/the-story-behind-flatten-the-curve-the-defining-chartof-the-coronavirus. (Set februar 2021).

Peter B. Andersen, lektor, ph.d. Religionsvidenskab, Københavns Universitet

Brian Arly Jacobsen, lektor, ph.d. Religionsvidenskab, Københavns Universitet

Lene Kühle, professor mso, ph.d. Religionsvidenskab, Aarhus Universitet

Henrik Reintoft Christensen, lektor, ph.d. Religionsvidenskab, Aarhus Universitet

Heidi Frølund Pedersen, Seniorforsker og psykolog, ph.d.

Funktionelle Lidelser, Aarhus Universitetshospital

Hanne Würtzen, klinisk psykolog, ph.d.

Tværfagligt Smertecenter, Rigshospitalet

Peter la Cour, lektor, ph.d. Institut for psykologi, Københavns Universitet

Jesper F.Sørensen, lektor, ph.d. Religionsvidenskab, Aarhus Universitet 